\title{
Getting a hold on archaeal type IV pili: an expanding repertoire of cellular appendages implicates complex regulation and diverse functions
}

\author{
Scott Chimileski* and R. Thane Papke \\ Department of Molecular and Cell Biology, University of Connecticut, Storrs, CT, USA
}

Keywords: haloarchaea, type IV pili, archaellum, surface adhesion, archaeal biofilm formation, microbial cell-tocell interactions

\section{A commentary on}

Novel pili-like surface structures of Halobacterium salinarum strain R1 are crucial for surface adhesion

OPEN ACCESS

Edited by:

Biswarup Mukhopadhyay,

Virginia Tech, USA

Reviewed by:

Sonja-Verena Albers,

University of Freiburg, Germany

Jerry Eichler,

Ben-Gurion University of the Negev

Israel

Mechthild Pohlschröder,

University of Pennsylvania, USA

${ }^{*}$ Correspondence:

Scott Chimileski,

scott.chimileski@uconn.edu

Specialty section:

This article was submitted to

Microbial Physiology and Metabolism,

a section of the journal

Frontiers in Microbiology

Received: 08 January 2015 Accepted: 10 April 2015

Published: 05 May 2015

Citation: Chimileski S and Papke RT (2015)

Getting a hold on archaeal type IV pill: an expanding repertoire of cellular appendages implicates complex regulation and diverse functions.

Front. Microbiol. 6:362

doi: 10.3389/fmicb.2015.00362 by Losensky, G., Vidakovic, L., Klingl, A., Pfeifer, F., and Fröls, S. (2014). Front. Microbiol. 5:755. doi: 10.3389/fmicb.2014.00755

Type IV pili (T4P) are a group of cell surface appendages of particular interest due to broad conservation and functional versatility across the domains Bacteria and Archaea (Albers and Meyer, 2011; Giltner et al., 2012). All T4P are composed of small protein subunits known as pilins that polymerize into helical fibers through the action of assembly ATPases (Giltner et al., 2012). This core ancestral machinery has been adapted in various lineages for many cellular processes-from adhesion and biofilm formation, to motility, horizontal gene transfer (HGT) and even electricity conduction (Giltner et al., 2012; Berry and Pelicic, 2015). When T4P structures are involved in adhesion, they are known as pili, if they no longer mediate attachment, but are associated with another function, such as scavenging macromolecules (e.g., DNA uptake by Com proteins in Bacillus subtilis), or secretion of proteins through a piston-like structure (i.e., type II secretion), they are called pseudopili (Averhoff and Friedrich, 2003; Peabody et al., 2003; Chen et al., 2005). T4P appendages may also contribute to both adhesion and another function. This dual function is sometimes true for archaella: a major group of archaeal T4P appendages characterized by the ability to rotate and enable swimming motility. Archaella are functionally analogous yet structurally and genetically unrelated to bacterial flagella (Jarrell and Albers, 2012; Shahapure et al., 2014; Albers and Jarrell, 2015). T4P have been studied to a greater extent in bacteria, in part because they are often virulence factors (Giltner et al., 2012). However, recent investigations have revealed a repertoire of archaeal T4P-highlighting implications for regulatory complexity and functional diversity.

Losensky et al. (2014) demonstrated that adhesive filaments in the haloarchaeon Halobacterium salinarum R1 observed during biofilm formation (Fröls et al., 2012) are dependent on the pilus assembly ATPase gene pilB1 (Losensky et al., 2014), expanding the list of experimentally studied archaeal T4P (Table 1). Deletion of pilB1 led to a lack of pili as observed through electron microscopy and a defect in adhesion. Only $4 \%$ of a glass surface was colonized by non-piliated/nonarchaellated cells ( $\triangle$ flaI/ $\Delta$ pilB 1 ), relative to 36 and $44 \%$ for the parental and non-archaellated $(\Delta$ flaI) strains, respectively. The molecular composition of PilB1-dependent pili has not yet been determined, however Losensky and coauthors noted that there are over 30 candidate pilins in the Hbt. salinarum R1 genome, as indicated by the class III signal peptide prediction program FlaFind (Szabó et al., 2007b). FlaFind was used previously to show that most archaeal genomes 
TABLE 1 | Experimentally studied type IV pili in archaeal species: archaella, adhesive pili, and pseudopili. ${ }^{a}$

\begin{tabular}{|c|c|c|c|c|}
\hline Structure name & $\begin{array}{l}\text { Function/ } \\
\text { associated phenotype }\end{array}$ & $\begin{array}{l}\text { Characterized } \\
\text { in (genera) }\end{array}$ & $\begin{array}{c}\text { Filament } \\
\text { diameter }(\mathrm{nm})\end{array}$ & References \\
\hline \multicolumn{5}{|l|}{ ARCHAELLA } \\
\hline & \multirow{7}{*}{$\begin{array}{l}\text { Swimming motility and involved in } \\
\text { adhesion in some species; } \\
\text { functionally analogous but } \\
\text { evolutionarily and structurally } \\
\text { distinct from the bacterial flagellab }\end{array}$} & Halobacterium & $10-15$ & $\begin{array}{l}\text { Alam and Oesterhelt, 1984; Gerl and } \\
\text { Sumper, 1988; Patenge et al., 2001; } \\
\text { Streif et al., } 2008\end{array}$ \\
\hline & & Haloferax & & Tripepi et al., 2010, 2012, 2013 \\
\hline & & Haloquadratum & & Alam et al., 1984 \\
\hline & & Sulfolobus & & $\begin{array}{l}\text { Szabó et al., 2007a; Lassak et al., } \\
\text { 2012b; Shahapure et al., } 2014\end{array}$ \\
\hline & & Methanococcus & & Bardy et al., 2002; Jarrell et al., 2011 \\
\hline & & Methanocaldococcus & & Bellack et al., 2011 \\
\hline & & Pyrococcus & & $\begin{array}{l}\text { Nather et al., 2006; Nather-Schindler } \\
\text { et al., } 2014\end{array}$ \\
\hline \multicolumn{5}{|l|}{ ADHESIVE PILI } \\
\hline Archaeal adhesive pilus (Aap) & Surface adhesion & Sulfolobus & 11 & Henche et al., 2012 \\
\hline Type IV pilus (Epd) & Surface adhesion & Methanococcus & 8.5 & $\begin{array}{l}\text { Vandyke et al., 2008; Wang et al., } \\
\text { 2008; Nair et al., } 2013\end{array}$ \\
\hline Type IV pilus (PilA) & Surface adhesion & Haloferax & $8-12$ & $\begin{array}{l}\text { Esquivel et al., 2013; Esquivel and } \\
\text { Pohlschröder, 2014, } 2015\end{array}$ \\
\hline PilB1-dependent adhesive pilus-like ${ }^{c}$ & Surface adhesion & Halobacterium & $7-8$ & Losensky et al., 2014 \\
\hline UV-inducible pilus (Ups) & $\begin{array}{l}\text { Autoaggregation and species } \\
\text { specific DNA exchange following } \\
\text { UV-irradiation }\end{array}$ & Sulfolobus & 10 & Fröls et al., 2008; Ajon et al., 2011 \\
\hline \multicolumn{5}{|l|}{ PSEUDOPILUS-LIKE } \\
\hline Bindosome assembly system (Bas) & $\begin{array}{l}\text { Sugar binding; } \\
\text { also involved in cellular morphology } \\
\text { and S-layer architecture }\end{array}$ & Sulfolobus & ND & Zolghadr et al., 2007, 2011 \\
\hline
\end{tabular}

ND, not determined.

${ }^{a}$ As reviewed by Pohlschröder et al. (2011), Lassak et al. (2012a), Jarrell et al. (2013) and Esquivel and Pohlschröder (2015).

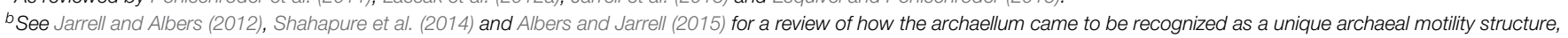
including a more comprehensive categorization of characterized archaella.

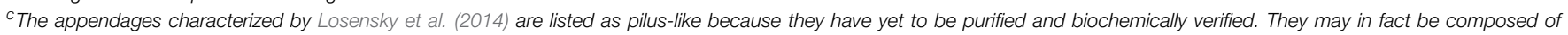
homologs of PilA pilin proteins in H. volcanii, which are found in many euryarchaeal species (Esquivel et al., 2013).

contain many pilin/archaellin homologs (Szabó et al., 2007b; Esquivel et al., 2013). For example, Haloarcula marismortui and Haloferax volcanii have nearly 50 putative pilin/archaellin precursors (Esquivel et al., 2013).

Some of these pilins could be associated with additional functions. Hfx. volcanii has an ability for social motility in static liquid (Chimileski et al., 2014) and T4P could be involved in this activity (Esquivel and Pohlschröder, 2015), whereby they may attach to extracellular matrix along the substratum, similar to the S-motility system that pulls Myxococcus xanthus cells forward (Hodgkin and Kaiser, 1979; Zusman et al., 2007). There could be more archaeal T4P-related surface structures that scavenge macromolecules as well, like the bindosome of Sulfolobus solfataricus (Zolghadr et al., 2007, 2011).

Investigations of archaeal T4P leave open the possibility for undiscovered mechanisms for contacting abiotic surfaces or other cells. For instance, even in the non-piliated/nonarchaellated Hbt. salinarum strain, adhesion was not completely abolished (Losensky et al., 2014). Similar residual adhesion has been observed in Hfx. volcanii (Tripepi et al., 2010, 2013). In both cases, pilins that remain present in the membrane but cannot be assembled into pili without the assembly ATPase(s) likely explain low levels of adhesion (Esquivel and Pohlschröder, 2014). There are two other cell-to-cell contact phenomena in Hfx. volcanii that do not require archaella or pili: $\mathrm{Ca}^{2+}$ dependent autoaggregation (Tripepi et al., 2010), and an HGT mechanism known as mating (Rosenshine et al., 1989; Tripepi et al., 2010; Naor et al., 2012). Additional types of extracellular polymers or fibers found in bacterial species could be present in archaea, such as amyloid protein (Chimileski et al., 2014). Unusual, genetically ambiguous non-T4P structures have already been observed in other archaeal species, including the hamus of the SM1 euryarchaeon (Moissl et al., 2005; Perras et al., 2014) and the cannulae of Pyrodictium cells (Nickell et al., 2003).

A plausible explanation for having a wide array of appendages is a capacity for differential regulation (Jarrell, 2012; Lassak et al., 2012a; Jarrell et al., 2013). Indeed, a number of studies point to dynamic regulatory systems controlling archaeal T4P. In Hbt. salinarum, pilB1 expression was upregulated relative to flaI in adherent cells (Losensky et al., 2014), suggesting archaella and pili have antagonistically regulated functions in motility (when a planktonic state is favorable) and for adhesion (during biofilm 
formation), as in $H f x$. volcanii (Tripepi et al., 2010; Esquivel and Pohlschröder, 2014, 2015). Haloarcula marismortui has two archaellins that are expressed under different temperatures and salinities (Syutkin et al., 2014), termed ecoparalogs. Likewise, the six Hfx. volcanii pilA paralogs, any one of which can restore adhesion when expressed in a null mutant $[\Delta$ pilA(1-6)] (Esquivel et al., 2013), may be ecoparalogs as well. Intriguingly, deleting $f l g A 2$, one of two archaellin genes in $H f x$. volcanii, produced a hypermotile phenotype, rather than a motility defect (Tripepi et al., 2013). Archaellins are also regulated through N-glycosylation (Guan et al., 2012; Tripepi et al., 2012) and regulatory proteins controlling adhesive pili and archaella have been identified in Sulfolobus acidocaldarius (Reimann et al., 2012; Orell et al., 2013; Vassart et al., 2013).

As more T4P are described in archaeal groups, a common theme is appearing. A multitude of individual pilins/archaellins

\section{References}

Ajon, M., Fröls, S., Van Wolferen, M., Stoecker, K., Teichmann, D., Driessen, A. J., et al. (2011). UV-inducible DNA exchange in hyperthermophilic archaea mediated by type IV pili. Mol. Microbiol. 82, 807-817. doi: 10.1111/j.13652958.2011.07861.x

Alam, M., Claviez, M., Oesterhelt, D., and Kessel, M. (1984). Flagella and motility behavior of square bacteria. EMBO J. 3, 2899-2903.

Alam, M., and Oesterhelt, D. (1984). Morphology, function and isolation of halobacterial flagella. J. Mol. Biol. 176, 459-475.

Albers, S.-V., and Jarrell, K. F. (2015). The archaellum: how archaea swim. Front. Microbiol. 6:23. doi: 10.3389/fmicb.2015.00023

Albers, S. V., and Meyer, B. H. (2011). The archaeal cell envelope. Nat. Rev. Microbiol. 9, 414-426. doi: 10.1038/nrmicro2576

Averhoff, B., and Friedrich, A. (2003). Type IV pili-related natural transformation systems: DNA transport in mesophilic and thermophilic bacteria. Arch. Microbiol. 180, 385-393. doi: 10.1007/s00203-003-0616-6

Bardy, S. L., Mori, T., Komoriya, K., Aizawa, S. I., and Jarrell, K. F. (2002). Identification and localization of flagellins FlaA and FlaB3 within flagella of Methanococcus voltae. J. Bacteriol. 184, 5223-5233. doi: 10.1128/jb.184.19.5223-5233.2002

Bellack, A., Huber, H., Rachel, R., Wanner, G., and Wirth, R. (2011). Methanocaldococcus villosus sp. nov., a heavily flagellated archaeon that adheres to surfaces and forms cell-cell contacts. Int. J. Syst. Evol. Microbiol. 61, 1239-1245. doi: 10.1099/ijs.0.023663-0

Berry, J. L., and Pelicic, V. (2015). Exceptionally widespread nanomachines composed of type IV pilins: the prokaryotic Swiss Army knives. FEMS Microbiol. Rev. 39, 1-21. doi: 10.1093/femsre/fuu001

Chen, I., Christie, P. J., and Dubnau, D. (2005). The ins and outs of DNA transfer in bacteria. Science 310, 1456-1460. doi: 10.1126/science.1114021

Chimileski, S., Franklin, M. J., and Papke, R. T. (2014). Biofilms formed by the archaeon Haloferax volcanii exhibit cellular differentitaion and social motility, and facilitate horizontal gene transfer. BMC Biol. 12:65. doi: 10.1186/s12915014-0065-5

Esquivel, R. N., and Pohlschröder, M. (2014). A conserved type IV pilin signal peptide $\mathrm{H}$-domain is critical for the post-translational regulation of flagella-dependent motility. Mol. Microbiol. 93, 494-504. doi: 10.1111/mmi. 12673

Esquivel, R. N., and Pohlschröder, M. (2015). Archaeal type IV pili and their involvement in biofilm formation. Front. Microbiol. 6:190. doi: 10.3389/fmicb. 2015.00190

Esquivel, R. N., Xu, R., and Pohlschröder, M. (2013). Novel archaeal adhesion pilins with a conserved $\mathrm{N}$ terminus. J. Bacteriol. 195, 3808-3818. doi: 10.1128/JB.00572-13

Fröls, S., Ajon, M., Wagner, M., Teichmann, D., Zolghadr, B., Folea, M., et al. (2008). UV-inducible cellular aggregation of the hyperthermophilic archaeon from one or more loci may appear to be redundant-contributing to appendages that are difficult to differentiate through electron microscopy and often depend on the same assembly ATPase. However, to the contrary, the maintenance of more than one pilus and archaellum subunit gene is likely due to a complex regulatory network and the corresponding advantages of functional versatility. Subsets of pilins may be expressed in different combinations as a response to a variety of specific environmental conditions and/or cellular functions.

\section{Acknowledgments}

RTP was supported by the National Science Foundation (award numbers DEB-0910290 and DEB-0830024) and the NASA Astrobiology: Exobiology and Evolutionary Biology Program (grant number NNX12AD70G).

Sulfolobus solfataricus is mediated by pili formation. Mol. Microbiol. 70, 938-952. doi: 10.1111/j.1365-2958.2008.06459.x

Fröls, S., Dyall-Smith, M., and Pfeifer, F. (2012). Biofilm formation by haloarchaea. Environ. Microbiol. 14, 3159-3174. doi: 10.1111/j.1462-2920.2012.02895.x

Gerl, L., and Sumper, M. (1988). Halobacterial flagellins are encoded by a multigene family. J. Biol. Chem. 263, 13246-13251.

Giltner, C. L., Nguyen, Y., and Burrows, L. L. (2012). Type IV pilin proteins: versatile molecular modules. Microbiol. Mol. Biol. Rev. 76, 740-772. doi: 10.1128/MMBR.00035-12

Guan, Z., Naparstek, S., Calo, D., and Eichler, J. (2012). Protein glycosylation as an adaptive response in Archaea: growth at different salt concentrations leads to alterations in Haloferax volcanii S-layer glycoprotein N-glycosylation. Environ. Microbiol. 14, 743-753. doi: 10.1111/j.1462-2920.2011.02625.x

Henche, A. L., Ghosh, A., Yu, X., Jeske, T., Egelman, E., and Albers, S. V. (2012). Structure and function of the adhesive type IV pilus of Sulfolobus acidocaldarius. Environ. Microbiol. 14, 3188-3202. doi: 10.1111/j.14622920.2012.02898.x

Hodgkin, J., and Kaiser, D. (1979). Genetics of gliding motility in Myxococcus xanthus (Myxobacterales): two gene systems control movement. Mol. Gen. Gentics 171, 177-191. doi: 10.1007/BF00270004

Jarrell, K. F. (2012). Control of archaellation in Sulfolobus acidocaldarius: unravelling of the regulation of surface structure biosynthesis in Archaea begins. Mol. Microbiol. 86, 1-5. doi: 10.1111/j.1365-2958.2012.08191.x

Jarrell, K. F., and Albers, S. V. (2012). The archaellum: an old motility structure with a new name. Trends Microbiol. 20, 307-312. doi: 10.1016/j.tim.2012.04.007

Jarrell, K. F., Stark, M., Nair, D. B., and Chong, J. P. (2011). Flagella and pili are both necessary for efficient attachment of Methanococcus maripaludis to surfaces. FEMS Microbiol. Lett. 319, 44-50. doi: 10.1111/j.1574-6968.2011.02264.x

Jarrell, K. F., Ding, Y., Nair, D. B., and Siu, S. (2013). Surface appendages of Archaea: structure, function, genetics and assembly. Life 3, 86-117. doi: 10.3390/life3010086

Lassak, K., Ghosh, A., and Albers, S. V. (2012a). Diversity, assembly and regulation of archaeal type IV pili-like and non-type-IV pili-like surface structures. Res. Microbiol. 163, 630-644. doi: 10.1016/j.resmic.2012.10.024

Lassak, K., Neiner, T., Ghosh, A., Klingl, A., Wirth, R., and Albers, S. V. (2012b) Molecular analysis of the crenarchaeal flagellum. Mol. Microbiol. 83, 110-124. doi: 10.1111/j.1365-2958.2011.07916.x

Losensky, G., Vidakovic, L., Klingl, A., Pfeifer, F., and Fröls, S. (2014). Novel pililike surface structures of Halobacterium salinarum strain R1 are crucial for surface adhesion. Front. Microbiol. 5:755. doi: 10.3389/fmicb.2014.00755

Moissl, C., Rachel, R., Briegel, A., Engelhardt, H., and Huber, R. (2005). The unique structure of archaeal "hami", highly complex cell appendages with nano-grappling hooks. Mol. Microbiol. 56, 361-370. doi: 10.1111/j.13652958.2005.04294.x

Nair, D. B., Chung, D. K., Schneider, J., Uchida, K., Aizawa, S., and Jarrell, K. F. (2013). Identification of an additional minor pilin essential for piliation 
in the archaeon Methanococcus maripaludis. PLoS ONE 8:e83961. doi: 10.1371/journal.pone.0083961

Naor, A., Lapierre, P., Mevarech, M., Papke, R. T., and Gophna, U. (2012). Low species barriers in halophilic archaea and the formation of recombinant hybrids. Curr. Biol. 22, 1444-1448. doi: 10.1016/j.cub.2012.05.056

Nather, D. J., Rachel, R., Wanner, G., and Wirth, R. (2006). Flagella of Pyrococcus furiosus: multifunctional organelles, made for swimming, adhesion to various surfaces, and cell-cell contacts. J. Bacteriol. 188, 6915-6923. doi: 10.1128/JB.00527-06

Nather-Schindler, D. J., Schopf, S., Bellack, A., Rachel, R., and Wirth, R. (2014). Pyrococcus furiosus flagella: biochemical and transcriptional analyses identify the newly detected flaB0 gene to encode the major flagellin. Front. Microbiol. 5:695. doi: 10.3389/fmicb.2014.00695

Nickell, S., Hergel, R., Baumeisiter, W., and Rachel, R. (2003). Pyrodictium cannulae enter the periplasmic space but do not enter the cytoplasm, as revealed by cryo-electron tomography. J. Struct. Biol. 141, 34-42. doi: 10.1016/S10478477(02)00581-6

Orell, A., Peeters, E., Vassen, V., Jachlewski, S., Schalles, S., Siebers, B., et al. (2013). Lrs14 transcriptional regulators influence biofilm formation and cell motility of Crenarchaea. ISME J. 7, 1886-1898. doi: 10.1038/ismej.2013.68

Patenge, N., Berendes, A., Engelhardt, H., Schuster, S. C., and Oesterhelt, D. (2001). The fla gene cluster is involved in the biogenesis of flagella in Halobacterium salinarum. Mol. Microbiol. 41, 653-663. doi: 10.1046/j.1365-2958.2001.02542.x

Peabody, C. R., Chung, Y. J., Yen, M. R., Vidal-Ingigliardi, D., Pugsley, A. P., and Saier, M. H. (2003). Type II protein secretion and its relationship to bacterial type IV pili and archaeal flagella. Microbiology 149, 3051-3072. doi: 10.1099/mic.0.26364-0

Perras, A. K., Wanner, G., Klingl, A., Mora, M., Auerbach, A. K., Heinz, V., et al. (2014). Grappling archaea: ultrastructural analyses of an uncultivated, cold-loving archaeon, and its biofilm. Front. Microbiol. 5:397. doi: 10.3389/fmicb.2014.00397

Pohlschröder, M., Ghosh, A., Tripepi, M., and Albers, S. V. (2011). Archaeal type IV pilus-like structures-evolutionarily conserved prokaryotic surface organelles. Curr. Opin. Microbiol. 14, 357-363. doi: 10.1016/j.mib.2011. 03.002

Reimann, J., Lassak, K., Khadouma, S., Ettema, T. J., Yang, N., Driessen, A. J., et al. (2012). Regulation of archaella expression by the FHA and von Willebrand domain-containing proteins ArnA and ArnB in Sulfolobus acidocaldarius. Mol. Microbiol. 86, 24-36. doi: 10.1111/j.1365-2958.2012.08186.x

Rosenshine, I., Tchelet, R., and Mevarech, M. (1989). The mechanism of DNA transfer in the mating system of an archaebacterium. Science 245, 1387-1389.

Shahapure, R., Driessen, R. P., Haurat, M. F., Albers, S. V., and Dame, R. T. (2014). The archaellum: a rotating type IV pilus. Mol. Microbiol. 91, 716-723. doi: $10.1111 / \mathrm{mmi} .12486$

Streif, S., Staudinger, W. F., Marwan, W., and Oesterhelt, D. (2008). Flagellar rotation in the archaeon Halobacterium salinarum depends on ATP. J. Mol. Biol. 384, 1-8. doi: 10.1016/j.jmb.2008.08.057

Syutkin, A. S., Pyatibratov, M. G., Galzitskaya, O. V., Rodriguez-Valera, F., and Fedorov, O. V. (2014). Haloarcula marismortui archaellin genes as ecoparalogs. Extremophiles 18, 341-349. doi: 10.1007/s00792-013-0619-4
Szabó, Z., Sani, M., Groeneveld, M., Zolghadr, B., Schelert, J., Albers, S. V., et al. (2007a). Flagellar motility and structure in the hyperthermoacidophilic archaeon Sulfolobus solfataricus. J. Bacteriol. 189, 4305-4309. doi: 10.1128/JB.00042-07

Szabó, Z., Stahl, A. O., Albers, S. V., Kissinger, J. C., Driessen, A. J., and Pohlschröder, M. (2007b). Identification of diverse archaeal proteins with class III signal peptides cleaved by distinct archaeal prepilin peptidases. J. Bacteriol. 189, 772-778. doi: 10.1128/JB.01547-06

Tripepi, M., Esquivel, R. N., Wirth, R., and Pohlschröder, M. (2013). Haloferax volcanii cells lacking the flagellin FlgA2 are hypermotile. Microbiology 159, 2249-2258. doi: 10.1099/mic.0.069617-0

Tripepi, M., Imam, S., and Pohlschröder, M. (2010). Haloferax volcanii flagella are required for motility but are not involved in PibD-dependent surface adhesion. J. Bacteriol. 192, 3093-3102. doi: 10.1128/JB.00133-10

Tripepi, M., You, J., Temel, S., Onder, O., Brisson, D., and Pohlschröder, M. (2012). $\mathrm{N}$-glycosylation of Haloferax volcanii flagellins requires known Agl proteins and is essential for biosynthesis of stable flagella. J. Bacteriol. 194, 4876-4887. doi: 10.1128/JB.00731-12

Vandyke, D. J., Wu, J., Ng, S. Y., Kanbe, M., Chaban, B., Aizawa, S., et al. (2008). Identification of a putative acetyltransferase gene, MMP0350, which affects proper assembly of both flagella and pili in the archaeon Methanococcus maripaludis. J. Bacteriol. 190, 5300-5307. doi: 10.1128/JB. 00474-08

Vassart, A., Van Wolferen, M., Orell, A., Hong, Y., Peeters, E., Albers, S. V., et al. (2013). Sa-Lrp from Sulfolobus acidocaldarius is a versatile, glutamineresponsive, and architectural transcriptional regulator. Microbiologyopen 2, 75-93. doi: $10.1002 / \mathrm{mbo} 3.58$

Wang, Y. A., Yu, X., Ng, S. Y., Jarrell, K. F., and Egelman, E. H. (2008). The structure of an archaeal pilus. J. Mol. Biol. 381, 456-466. doi: 10.1016/j.jmb.2008.06.017

Zolghadr, B., Klingl, A., Rachel, R., Driessen, A. J., and Albers, S. V. (2011), The bindosome is a structural component of the Sulfolobus solfataricus cell envelope. Extremophiles 15, 235-244. doi: 10.1007/s00792-010-0353-0

Zolghadr, B., Weber, S., Szabó, Z., Driessen, A. J., and Albers, S. V. (2007). Identification of a system required for the functional surface localization of sugar binding proteins with class III signal peptides in Sulfolobus solfataricus. Mol. Microbiol. 64, 795-806. doi: 10.1111/j.1365-2958.2007.05697.x

Zusman, D. R., Scott, A. E., Yang, Z., and Kirby, J. R. (2007). Chemosensory pathways, motility and development in Myxococcus xanthus. Nat. Rev. Microbiol. 5, 862-872. doi: 10.1038/nrmicro1770

Conflict of Interest Statement: The authors declare that the research was conducted in the absence of any commercial or financial relationships that could be construed as a potential conflict of interest.

Copyright $\odot 2015$ Chimileski and Papke. This is an open-access article distributed under the terms of the Creative Commons Attribution License (CC BY). The use, distribution or reproduction in other forums is permitted, provided the original author(s) or licensor are credited and that the original publication in this journal is cited, in accordance with accepted academic practice. No use, distribution or reproduction is permitted which does not comply with these terms. 